sciendo Порівняльна професійна педагогіка 8(2)/2018

Comparative Professional Pedagogy 8(2)/2018

DOI: $10.2478 /$ rpp-2018-0034

Postgraduate Student, VITALII BARBINOV

V. H. Korolenko Poltava National Pedagogical University, Ukraine Address: 2 Ostrohradskyi St., Poltava, 36000, Ukraine

E-mail: shov2016@ukr.net

\title{
VOCATIONAL TRAINING OF FUTURE AGRICULTURAL SPECIALISTS: EUROPEAN EXPERIENCE
}

\begin{abstract}
The article focuses on vocational training of future agricultural specialists in the context of European experience. Thus, theoretical framework of the research has been thoroughly justified. It includes the prominent documents of European authorities such as the Charter of European Agricultural Education, CAP context indicators for 2014-2020, European Parliament's publications, Eurostat statistics such glossary of farmers training level terms, as well as respected researches of many European scholars (A. Miceli, A. Moore, M. Mulder et al.). It has been found that European approach to organizing vocational training of future agricultural specialists is rather multiaspect and strives to fulfill educational needs of majority of learners, namely, through practical agricultural training, basic agricultural training and full-time agricultural trainings. It has been clarified that more and more young people realize the importance of the agricultural sector to the overall prosperity of the European Union; therefore they seek quality vocational training based on relevant vocational schools. It has been stated that European Union constantly develops various strategies for developing the agricultural sector, in particular through enhancing quality of future agricultural specialists' vocational training. It has been defined that despite the fact that low incomes, certain risks, uncertainties in an economic environment due to globalization processes may somehow discourage younger generations to pursue career in agriculture, the CA implements different mechanisms for sustaining stable development of agricultural education. It has been specified that such countries as France and Germany regularly update the content of agricultural education so that it takes into account the trends in vocational training of future agricultural specialists opportunity and allows applying the most advanced teaching technologies, promoting knowledge significance, widening access to all levels of education, implementing a system of lifelong learning, individualizing agricultural education. It has been outlined that the prospects for further studies are seen in studying the most important aspects in the legal framework of the agricultural education system in innovative experience of European countries, the USA, Canada, Australia, etc.
\end{abstract}

Keywords: agricultural sector, agricultural education, agricultural science, future agricultural specialists, vocational training, European experience.

\section{INTRODUCTION}

The main aim of Ukrainian education modernization is to ensure efficient vocational training of future skilled workers, who are able to be competitive in the labour market. Therefore, dynamic changes taking place in the labour market require vocational schools graduates not only to develop their professional competency, but also to be ready to respond promptly to changes in technology, science, society and economics. It must be 
noted that socioeconomic transformations in Ukraine have also resulted in the need for modernizing vocational training of future agricultural specialists. As evidenced by the legal documents, the current state of the country's economy requires that a system for enhancing the agricultural sector, namely, through sustaining the paradigm "agricultural educationagricultural science - agricultural production", should be developed.

Theoretical analysis of researches on the issue of developing readiness of future agricultural specialist for professional activity shows that the process of solving this issue is complicated by a range of contradictions between: 1) increasing requirements of society to future agricultural specialists' vocational training, who should be able to work efficiently under modern socioeconomic, technological and informational conditions and the current inefficient system of their training in vocational schools; 2) the need for designing a scientifically justified model for developing readiness of future agricultural specialists for professional activity in vocational schools and its insufficiently developed theoretical and methodological principles; 3 ) the need for applying modern pedagogical technologies while forming readiness of future agricultural specialists for professional activity and inefficient mechanisms of their optimal use in the education process.

In order to resolve the above-mentioned contradictions, to enhance quality of future agricultural specialists' vocational training and adjust the content of these specialists' training in Ukraine to European and global standards, it is imperative to study relevant foreign experience, to outline its most positive aspects and elaborate the mechanisms for their implementing into the national system of vocational education, in particular vocational training of future agricultural specialists.

\section{THE AIM OF THE STUDY}

The research aims to characterize vocational training of future agricultural specialists in European experience and outline its most positive aspects, which can be efficiently implemented into the system of vocational education in Ukraine.

\section{THEORETICAL FRAMEWORK AND RESEARCH METHODS}

Agricultural education prepares the future generation of leaders, researchers, professionals, technicians and innovative farmers, who can collectively meet the global challenges of sufficient food and food security (Mulder, 2008, p. 221). M. Mulder, one of the authors of the Handbook of Technical and Vocational Education and Training Research, clearly highlights the main aim of the agriculture sector, namely, to ensure prosperity of mankind due to the efforts of highly skilled agricultural specialists, who are expected to obtain quality agricultural vocational education. However, he indicates that agricultural education differs significantly worldwide (Mulder, 2008, p. 224). Thus, there are higher education institutions that teach agricultural subjects as optional courses, as well as specific schools that provide vocational agricultural education. As for the curriculum content, agricultural education has diversified considerably. Indeed, some agricultural education institutions may not even maintain such concepts as "agriculture" or "agricultural" in their names. Presently, minority of students is enrolled in programmes that are majority is enrolled in geo-informatics, biotechnology, farm management, business management, economics, sociology, consumer, food and nutrition, health and communication, environmental programmes. So, it can be concluded that agricultural education has significantly broadened. It must be noted, this process is still going on.

In this regard, European experience should be taken into account, since its "common agricultural policy (CAP) has been the biggest, the most contentious and the one 
sciendo Порівняльна професійна педагогіка 8(2)/2018

Comparative Professional Pedagogy 8(2)/2018

with the largest budget of all the Union's policy areas. The EU has more power in agricultural policy than it has in any other policy area and it has passed more legislation on agriculture than in any other single policy area" (Miceli, 2005, p. 9).

It must be noted that in Europe the younger generations hesitate to pursue career in agriculture, too. It can be explained by hard working conditions, low incomes, long hours, many risks and uncertainties in an economic environment due to globalization processes. Therefore, the EU, through CAP, assists young agricultural specialists due to various mechanisms, which support them while entering the agricultural sector. So, the CAP aims to ensure the continuity of future agricultural specialists' vocational training. They emphasize on the fact that future agricultural specialists should be obtain relevant training to adapt to increasingly specialized agricultural technologies. In addition, the CAP also funds training and operation of farm advisory systems (European Parliament, 2017, p. 2).

Thus, theoretical framework of current research will include official documents issued by European authorities, additional resources on the problem of future agricultural specialists' training and some overview of practical aspects of such training. While researching, we used such methods theoretical analysis, individualization and generalization, deduction.

\section{RESULTS}

According to the European Union statistical office (Eurostat), there are three levels of agricultural education:

- practical agricultural experience: experience that is acquired while working on a farm;

- basic agricultural training: any courses completed at a general agricultural college or an institution, which specialize in certain subjects (agricultural technology, sylviculture, horticulture, pisciculture, viticulture, veterinary science); a completed agricultural apprenticeship is considered basic training;

-full-time agricultural training: any course continuing for the equivalent of at least two years full-time training after the end of compulsory training, completed at an agricultural college or at university, in agricultural technology, sylviculture, horticulture, pisciculture, viticulture, veterinary science, etc. (Eurostat Statistics Explained, 2018).

Eurostat data from 2013 show that countries with the highest shares of fullytrained farm managers include Luxembourg (50 \%), the Czech Republic (34,6 \%), France $(29.3 \%)$, Latvia $(28.4 \%)$, Poland (27.6 \%) and Austria (27.2\%). In the countries that joined the Union in 2004 and after, practical experience as the only basis for managing a farm is particularly prevalent: $80.7 \%$ of farmers have not been formally trained in agriculture. The share of fully-trained farmers is highest among the youngest EU farmers (under 35 years old), especially in Luxembourg $(66.7 \%)$ and France $(70.8 \%)$. In the member States that joined the Union in 2004 and after, more than $61 \%$ of young farmers on average rely on practical experience alone, this figure reaching $93.1 \%$ in Romania (European Commission, 2014, p. 109).

Based on Eurostat figures, one can state that young agricultural specialists tend to start their careers equipped with the relevant diploma, acquired in their country's agricultural education system. In all EU member states, agricultural education is an integral part of general education and training. It is mainly aimed at students who wish to pursue a career in the land-based sector, either as an employee or a manager. There are different levels of attaintment, ranging from basic certificates to engineering degrees of $\mathrm{PhDs}$ in agronomy. The organization of agricultural education varies according to the various national education systems. It can be centralized or partly devolved to regions (as in Germany). It includes initial vocational training, apprenticeship, undergraduate and postgraduate 
higher education. Agricultural education is usually regulated by either the Ministry of Agriculture or the Ministry of Education (European Parliament, 2017, p. 5).

Theoretical analysis of German agricultural education has revealed its certain peculiarities. First, it is built on the rational combination of theoretical and practical training. The level of these specialists' vocational training is rather high. Second, one of the main principles of higher education in Germany is academic freedom. Its specificity consists in the fact that every student can independently determine the list of the subjects they would like to study. Every semester consists of lecture (14-20 weeks) and non-lecture periods, during which the student is engaged in independent research activities. The main type of student preparation is independent work (the student should study the topic beforehand, and at the lecture the professor only makes highlight its main points and explains unclear aspects). Given the specifics of agricultural education, in which theoretical and practical knowledge is very closely intertwined, it is impossible to obtain a diploma of a qualified specialist without sufficient practical knowledge. Therefore, German institutions of agricultural education are equipped with relevant training facilities, namely modern farms, where students can master the main principles of agriculture management and agricultural products processing (Federal Ministry of Education and Research, 2005).

The German government pays much attention to higher agricultural education. All profits from the sale of products produced at educational farms constitute internal investment in the education process, and the educational agricultural enterprises pay only tax on turnover. The government's interest in developing this sector of education can be also proved by the fact that it provides a long-term interest-free loan in order to develop the production of educational farms and to supply them with new agricultural machinery free of charge for a year.

So, the main task of German agricultural policy is to prepare a highly qualified and educated, competitive agricultural specialist.

In France, higher agricultural education is characterized mainly by a flexibile and variable structure, which provides everyone with access to this field.

Thus, the modern system of French education, including agricultural education, is considered to be one of the most innovative in the world. Its main feature consists in the fact that there prevail state educational institutions, which are funded by the French government. In turn, the education process in private educational institutions is also under the strict control of state structures. Due to this aspect, the quality of higher education in the country is quite high, and French diplomas are recognized worlwide.

In France, higher education institutions are entitled to establish the centers for independent learning. Students who attend these centers receive a diploma for mastering an intensive training course after they have successfully passed the exams. Those students who have obtained specialized training in their institution of higher agricultural institution receive an additional diploma for undergoing an intesntive training in agriculture, for example a diploma of an agricultural engineer, in which the name of their education institution is indicated.

All researches in the field of agriculture are conducted at traditional institutes such as ISA Lille, a French Graduate School of Agriculture and Bioengineering; ESA Ecole Superieur d'Agriculture in Angers; the Institut National Agronomique Paris-Grignon (INA P-G), which is part of AgroParisTech now. All these institutions are considered to be the bearers of theoretical knowledge and are focused on training future researchers in the field agriculture. At universities, both agricultural and food and agricultural specialists are trained. Within the framework of this training there are: 
sciendo Порівняльна професійна педагогіка 8(2)/2018

Comparative Professional Pedagogy 8(2)/2018

- university institutes of technology (IUT), which provide a two-year preparation of an undergraduate technical diploma called a Diplôme universitaire de technologie (DUT) with specialization in agriculture and biotechnology;

- the first cycle education, which results in obtaining a general academic studies degree or the Diplôme d'études universitaires générales (DEUG) in the fields associated with agriculture, environment, as well as agricultural management, etc;

- the second cycle education, which allows obtaining a licentiate degree, so that graduates may be entitled to teach (The Ministry of Agriculture and Fishery, 2018).

It must be noted that students obtain theoretical and practical training through attending classes in colleges and gaining practical experience on farms. They are encouraged to participate in international exchange programmes to widen their educational and professional horizons. University students willing to study abroad can enroll in Erasmus+ (European Parliament, 2017).

So, due to different levels, cycles and diverse forms, French multifunctional system of higher agricultural education is becoming increasingly accessible and open to representatives of various societies and communities.

\section{CONCLUSIONS}

So, the overview of agricultural education in Europe shows that European approach to organizing vocational training of future agricultural specialists is rather multiaspect and strives to fulfill educational needs of majority of learners, namely, through practical agricultural training, basic agricultural training and full-time agricultural trainings. As evidenced by Eurostat data, more and more young people realize the importance of the agricultural sector to the overall prosperity of the European Union, therefore they seek quality vocational training based on relevant vocational schools. In turn, European Union constantly develops various strategies for developing the agricultural sector, in particular through enhancing quality of future agricultural specialists' vocational training. Despite the fact that hard working conditions, low incomes, long hours, many risks and uncertainties in an economic environment due to globalization processes may somehow discourage younger generations to pursue career in agriculture, the common agricultural policy, that is CAP, implements different mechanisms for sustaining stable development of agricultural education. Indeed, such countries as France and Germany regularly update the content of agricultural education so that it takes into account the trends in vocational training of future agricultural specialists and allows applying the most advanced teaching technologies, promoting knowledge significance, widening access to all levels of education, implementing a system of lifelong learning, individualizing agricultural education.

We consider it necessary to expand the conceptions of specialties, which should be studied within the system of agricultural education. As evidenced by European experience, the agricultural sector does not include only land-based occupations. Due to globalization and integration processes, the interdisciplinary prevails; therefore it is essential to view biotechnology, environment friendly technologies as the most progressive in the context of developing the agricultural sector.

It must be noted that the following suggestions can be realized to improve the system of future agricultural specialists' vocational training in Ukraine, namely, reforming the network of agrarian higher education institutions through establishing independent learning centers for those who wish to pursue career in agriculture; outlining methodological principles for improving the content of agricultural specialists' vocational training in accordance with the requirements of the Bologna Declaration and modern agricultural production, etc. 
The prospects for further studies are seen in studying the most important aspects in the legal framework of agricultural education as part of the system of vocational training in innovative experience of European countries, as well as the USA, Canada, Australia, etc.

\section{REFERENCES}

1. EUROPEA. (1999). The Charter of European Agricultural Education. Retrieved from http://europea.org/wp-content/uploads/2013/10/europea_charter_english.pdf.

2. European Commission. (2014). CAP context indicators 2014-2020. Retrieved from https://ec.europa.eu/agriculture/sites/agriculture/files/cap-indicators/context/2016/fulltext_en.pdf\#page $=111$.

3. European Parliament. (2017). Agricultural education and lifelong training in the EU. Retrieved from http://www.europarl.europa.eu/RegData/etudes/BRIE/2017/608788 /EPRS_BRI(2017)608788_EN.pdf.

4. Eurostat Statistics Explained. (2018). Glossary: farmers training level. Retrieved from http://ec.europa.eu/eurostat/statistics-explained/index.php/Glossary:Farmers_training_level.

5. Federal Ministry of Education and Research. (2005). Reform of vocational education and training in Germany. The 2005 Vocational Training Act (Berufsbildungsgesetz 2005). Retrieved from https://www.bmbf.de/pub/The_2005_ Vocational_ Training_Act.pdf.

6. Miceli, V. (2005). EU agricultural policy: the concept of multifunctionality and value added agriculture. Retrieved from http://centridiricerca.unicatt.it/cranec-crn0504.pdf.

7. Moore, A. (2004). The good teacher: dominant discourses in teaching and teacher education. London; New York: RoutledgeFalmer.

8. MTA. (2011). Continued vocational training for agricultural workers in the European Union. A substitute for inadequate initial training, an opportunity to develop skills and the need to promote worker mobility. Report from the second seminar organized by Geopa-Copa-Copa on the implementation of the European Agreement of 5 December 2002 on Vocational Training in Agriculture. Retrieved from http://www.copa-cogeca. be/Download.ashx?ID=891150\&fmt=pdf.

9. Mulder, M. (2008). Agriculture. In F. Rauner \& R. Maclean (Eds.), Handbook of Technical and Vocational Education and Training Research (pp. 221-238). Berlin: Springer Science and Business Media.

10. Mulder, M. (2015). Agricultural education and European vocational education policy-making. Journal of Agricultural Education and Extension, 21 (4), 289-292.

11. Spiller, A., \& Voss, J. (2008). Vocational training in the field of agriculture: empirical results. Retrieved from http://ageconsearch.umn.edu/bitstream/7876/1/cp070024.pdf.

12. The Ministry of Agriculture and Fishery. (2018). Higher and technical agricultural education in France. Retrieved from http://www.formation-agricole-bretagne. fr/fileadmin/user_upload/2006_enseignement_agricole_vanglaise_1_.pdf. 